\title{
ENVIRONMENTAL CONTROL ON THE END OF THE DOLOMIA PRINCIPALE/HAUPTDOLOMIT DEPOSITIONAL SYSTEM IN THE CENTRAL ALPS: COUPLING SEA-LEVEL AND CLIMATE CHANGES
}

\author{
Fabrizio Berra, Flavio Jadoul \& Andrea Anelli
}

Università degli Studi di Milano, Dipartimento di Scienze della Terra “A. Desio” - Italy

(E-mail: fabrizio.berra@unimi.it)

\begin{abstract}
The Norian in the Western Tethys is characterised by the deposition of early-dolomitised inner platform facies (Dolomia Principale/Hauptdolomit, DP/HD), bordered on the landward side by terrigenous coastal deposits (Keuper) and on the seaward side by calcareous backreef and reefal facies (Dachstein Limestone) passing basinward to open-sea sediments (Hallstatt facies). The inner carbonate platform is locally (Lombardy Basin, Carnic Alps, Central Austroalpine) dissected by normal faults leading to the development of intraplatform troughs.

Close to the Norian-Rhaetian boundary, sedimentation records an abrupt environmental change both on platform top and basins all over the Western Tethys (e.g. Western Carpathians, Transdanubian Range, Alps, Central Apennine). The top of the Dolomia Principale locally emerged, reflecting a major eustatic sea-level fall. Emersion is recorded in favourable settings by the development of polycyclic paleosols up to $30 \mathrm{~m}$ thick. In the Norian intraplatform basins, the succession is capped by 4 to 8 meters of thin-bedded, fine-grained limestones yielding abundant remnants of fishes and terrestrial reptiles. Fossil concentration as well as sedimentological features are indicative of reduced sedimentation rates due to decreased carbonate production, induced by the emersion of the platform top. The sea-level fall was followed by deposition of mixed fine-grained siliciclasticcarbonate successions (e.g. Riva di Solto Shale, Kössen beds, "Rhaetavicula contorta beds", Fatra Formation).

Stratigraphic evidence indicates a dry climate in the Western Tethys during the Norian, as indicated by the presence of evaporites (Burano, Apennine) and arid to semi-arid coastal to playa settings (Upper Keuper, Germany). In contrast, the basal layers of the basinal shales show evidence of wet climate.
\end{abstract}


The end of the Norian depositional system records two different phenomena: 1) an important sealevel fall was responsible for the emersion of the platform top and deposition of a condensed horizon in the basins; and 2) transition from dry to humid climate. The observed evolution is explained with a global cooling which caused the rapid sea-level fall responsible for the abrupt end of the DP/HD depositional system and the shift of the boundary between arid and temperate climate belts, which modified the distribution and amount of rainfall, triggering the deposition of shales along the Western Tethys margin.

Key words: Tethys, Norian, Rhaetian, climate change, sea-level fall, carbonate platform

\section{Introduction: climate, rainfall, sea-level changes and sedimentation}

Sea-level falls are recorded by facies changes which are often associated to subaerial exposure and to shifts in the depositional environment, resulting in a forced regressive trend (i.e. Coe et al., 2003). Glacialism represents the most efficient process to explain rapid sea-level falls, even in greenhouse conditions. It has been recently demonstrated (Miller at al., 2003; Bronimann et al., 2008) that even during the supergreenhouse Cretaceous period, rapid eustacy was driven by polar ice. Major and rapid sea-level falls are therefore mainly related to global cooling episodes which affected sea-level because of increase of volume of the polar ice, to the increase in the amount of fresh water stored in continental settings (in underground water tables or lakes; Jacobs \& Sahagian; 1993) or to thermal expansion/retraction of oceanic waters (Schulz \& Schäfer-Neth, 1997).

Relatively small changes in ice volume coupled with climate-induced changes in ground water storage and changes in the temperature of sea-water could have the potential to induce eustatic changes which may be of the amplitude recorded in the global curves of sea level changes even in time intervals, as the Triassic, when evidence of large ice caps is missing (Price, 1999; questioned evidences of ice caps during the Triassic are described from Southern Gondwana, Australia; Spenceley, 2001).

Global cooling is therefore responsible for the changes in sea level, but also for the shift of the zonal climate belts (Perlmutter \& Mattews, 1989; Mattews \& Perlmutter, 1994). In a zonal climate pattern, the transition from maximum to minimum conditions changes the relative size of the Hadley circulation cells. The simple zonal model is complicated by the presence of azonal climate patterns which are the result of local effects, such as the position of oceans and large landmasses, coast orientations, wind directions, oceanic currents and elevation of continental areas. Major azonal effects are recorded near the margins of land and sea. Global climate changes, beside 
shifting zonal climate belts, enhance or diminish the effects of azonal climate patterns (Mattews \& Perlmutter, 1994). Duration, frequency and intensity of global climate changes is function of the interaction, constructive and destructive, of orbital cycles with different frequency (cycles can be in phase or not) but also to non-periodic events (i.e. volcanic events; impacts). When positive interactions occur, global climate changes force Hadley circulation cells to shift latitudinal positions, thus, changing the position of dry vs. humid belts (Mattews \& Perlmutter, 1994) This model is supported by the measured effects of the present-day global warming. Recent studies indicate that warming caused a small increase in global mean precipitation (Zhang et al., 2007) but significantly affected its distribution. Warming is responsible for increasing precipitation at high latitudes and decreasing precipitation at sub-tropical latitudes (Dore, 2005; Zhang et al., 2007). This effect is extremely important for the position of the tropical belt which is now shifting toward the north (Seidel et al., 2008). This line of evidence suggests that the opposite situation can be expected with a global cooling. In this scenario, the transition zone between climate belts is extremely sensitive to climate changes, in terms of temperature and amount of rainfall. Climate may shift from arid/semiarid conditions during warm periods to semihumid/humid conditions during cold intervals between $25^{\circ}$ and $35^{\circ}$ latitude (belt 4A and 4B of Mattews \& Perlmutter; 1994), but at higher or lower latitude the climate shift is opposite. This situation can be complicated by the presence of azonal effects. Climate changes heavily affect the precipitation patterns, which play a major role in sediment delivery, as changes in precipitation are locally more efficient that sea-level fall (i.e. lowering of the depositional base level) in mobilising sediments toward the sea (Mattews \& Perlmutter, 1989).

Sedimentary environments highly sensitive both to climate (dry vs. humid) and to sea-level changes are represented by shallow-water carbonate platform systems. Tropical carbonate factories bordering emerged lands (attached platforms) are able to record both the changes in the efficiency of the factory itself and in the quantity of the clastic delivered from the emerged lands, as a response to increased rainfall and/or changes of the erosional base level. Furthermore, emersion of rimmed, flat-topped platforms is reflected also by major facies changes of platform-derived carbonates in basinal settings, allowing to trace the evidence of a sea-level fall from the platform top to the basins (i.e. Berra, 2007). In flat-topped carbonate factories even reduced sea-level fall can led to the emersion of vast parts of the carbonate system.

Sedimentological analyses in these settings could help to determine how clastic input postdating a sequence boundary in carbonate systems is related to/enhanced by climate changes. The NorianRhaetian succession of the Western Tethys margin records important changes in carbonate 
production and facies association, both on platform top and intraplatform basins, resulting from the interaction of sea-level fall and climate change (from dry and warm to humid and cooler).

\section{Geological setting}

Influence of climate on basin stratigraphy is a function of the geographic position of the basin itself (Perlmutter \& Mattews, 1989). It is thus essential to frame the latitudinal position of the DP/HD depositional system close to the Norian-Rhaetian boundary. During the Norian and Rhaetian the present-day Alpine successions were placed at about N 25 (Marcoux et al., 1993). Sedimentation on the Tethys margin was characterised for most of the Norian by a wide, early-dolomitised carbonate platform succession (Dolomia Principale/Hauptdolomit, DP/HD) which is presently preserved different domains: Southern Alps, Central and Northern Austroalpine, Transdanubian Range, Western Carpathians and Southern Apennines (Fig. 1). Landward, sedimentation changed to coastal and playa deposits (Keuper). Toward the Tethys, the wide inner platform of the DP/HD was bordered by calcareous backreef and margin facies (Dachstein Lst.) which pass basinward to deep water sediments (Hallstatt Lst.). The evolution of the DP/HD platform is locally controlled by syndepositional tectonics which was responsible for the development of fault-controlled intraplatform basins, both in the Austroalpine and South Alpine domains during the Middle-Late Norian (Jadoul, 1985; Bechstadt et al., 1987; Jadoul et al., 1992; Berra \& Jadoul, 1996; Berra, 1995; Berra \& Jadoul, 1999; Cozzi et al., 2002; Fig. 2). Due to the extensional tectonics, the top of the $\mathrm{DP} / \mathrm{HD}$ system is characterized by domains where the flat-topped platform persisted and domains where tectonically-induced drowning is recorded by thick basinal successions. The syndepositional tectonics was responsible for major thickness changes of the Norian succession, from a few hundreds of meters (carbonate highs, e.g. Dolomites) to more than $2 \mathrm{~km}$ (intraplatform troughs). The major basinal areas are developed in the Central Southern Alps (Lombardy Basin), in the Eastern Southern Alps (Carnia; Cozzi, 2002), in the Central Austroalpine (Ortles and Quattervals Nappes; Berra, 1995; Berra \& Jadoul, 1999), in the Northern Calcareous Alps (Seefeld Basin; Fruth \& Scherreiks, 1984) and in the Apennines (Cirilli et al., 1999; Zamparelli et al., 1999).

Sedimentation in the fault-controlled intraplatform basins is mainly characterised by platformderived turbiditic limestones and scarp breccias (i.e. Jadoul, 1985), fed by the DP/HD highs. The end of the DP/HD system is marked along the Tethys margin by the end of the early dolomitization (Frisia, 1991) and by the input of fine-grained clastics which have different names despite their common sedimentological and environmental features (Kössen Fm., Riva di Solto Shale-Zu Limestone, "Rhaetavicula contorta beds", Fatra Fm.). The boundary between the DP/HD 
system and the overlying shaly and marly units is sharp and can be traced all along the Tethys margin, from Western Carpathians to Northern Apennines.

Biostratigraphical data from continuous successions suggest a synchronous age for this environmental change. Due to the absence of a GSSP for the Norian-Rhaetian boundary, the attribution of a unit to one or to the other stage can be misleading if the fossil associations are not considered. The base of the Kössen Beds is dated at the Misikella hernsteini zone (Kachroo, 1989; Golebiowski, 1990; Haas \& Budai, 1995) which has been recently suggested as latemost Norian or early Rhaetian (Krystyn et al., 2007) and coincide with the basal part of Sevatian 2 (Paracochloceras suessi zone). In the Southern Alps, conodont assemblages (Jadoul et al., 2007; Rigo et al., 2009), document that the Riva di Solto Shale was deposited (at least the middle-upper part) during the Misikella hernsteini zone (Sevatian 2) whereas the deposition of the Zu Limestone began at the base of the $M$.hernsteini - M. posthernsteini zone. The attribution of the beginning of the Kössen Formation in the Central Austroalpine (Berra \& Cirilli, 1996) to the Sevatian stands on palynological assemblages which are referred to the phase III of Schuurman (1979). Accordingly, biostratigraphic constraints from different domains of the Tethys margin strongly place the beginning of the input of shales along the Tethys margin to the Misikella hernsteini zone (Sevatian 2). In the text, we will refer to the age of this environmental change (M. hernsteini zone) as "close to the Norian-Rhaetian boundary".

In the basinal settings the Hallstatt Limestone is covered by the Zlamback Marl (Zankl, 1971), whose basal breccias are coeval with the base of the Kössen Formation (Krystyn et al., 2007). Where shales were not deposited (i.e. on structural highs as the Dolomites or far from the Norian coast, such as Southern Apennines) the end of the DP/HD system is marked by a shift from earlydolomitised to calcareous carbonate deposits (i.e. "Rhaetian" Dachstein Limestone in the Dolomites) along with a change in the faunal association. The beginning of the shaly input ( $M$. hernsteini zone) does not represent everywhere the age of the first deposits which cover the HD/DP system, as hiatuses before the deposition of shales are documented on the carbonate highs.

Paleosols and erosional surfaces are locally preserved on the DP/HD highs which bordered the major intraplatform troughs. In contrast to the carbonate highs, sedimentation was continuous in the deeper basins and characterised by a sharp lithological change, marked by the deposition of dark shales above the bedded turbiditic limestones.

The end of the DP/HD carbonate system is associated to a major sea-level fall (whose origin is likely related to eustacy; Gaetani et al., 1998), which can be traced across different sedimentary basins. A sequence boundary at the top of the DP/HD system is recognized in the Eastern Southern Alps by Gianolla et al. (1998), but also in the Western Carpathian (Feist-Burkhardt et al., 2008). 
Embry (1997) considers the sea level fall at the top of the Dolomia Principale of the Southern Alps a global event which can be traced worldwide. A major unconformity is recorded at this stratigraphic position also in the Germanic Basin (German Stratigraphic Commission, 2002; Kozur and Bachmann, 2005).

In the central Southern Alps, the syndepositional tectonics (Jadoul et al., 1994) probably locally enhanced the effects of the sea-level fall. Nevertheless, even if extensional tectonics were active during most of the Norian in the central Southern Alps, emersions are recorded only at the top of the Norian platform, suggesting that tectonics alone can not explain the emersion of the platform top at this stratigraphic position. Furthermore, the topmost Dolomia Principale is locally characterized by a progradational trend on the scarp breccias immediately before the deposition of shales (Berra \& Jadoul, 1996), reflecting a decreased accommodation space, compatible with a sealevel fall.

Where fine terrigenous sedimentation occurred, the recovery of the carbonate production after the end of the DP/HD system was gradual, as documented by the progressive increase in carbonate content within the fine-grained clastic successions ( $\mathrm{Zu}$ Formations, middle to upper Kössen beds; with a major coral limestone layer known as "Banco a Coralli" or "Hauptlithodendronkalk"). The latemost Norian-Rhaetian clastic sediments often pinches out above the DP/HD highs, whereas their thickness may reach up to several tens to hundreds of meters in the intraplatform troughs.

The different sedimentological expression of the environmental change at the top of the DP/HD system has been investigated both in the basins and on the carbonate highs in different paleogeographic settings (Southern Alps and Ortles Nappe, Central Austroalpine), in order to define the relationships between sea-level fall and environmental changes.

\section{Sequence boundary on top of the DP/HD system: sedimentological features}

Despite the huge extension of the DP/HD depositional basin, the similarity in the stratigraphic evolution is surprising, even in sections which were deposited several tens of km apart (Fig. 3). The shift in sedimentation recorded along the Tethys margin at the end of the deposition of DP/HD, is recorded both on the platforms (Lombardy Basin, Brenta Dolomites, Dolomites, Central Austroalpine) and in the intraplatform basins (central Lombardy Basin, Tremalzo Basin). The shaly succession which covers the DP/HD system is locally characterised by major thickness changes which reflect the previously developed horst and graben topography related to the Middle-Late Norian extensional tectonics. 


\section{1) Sedimentary evolution on the platform top}

During the Middle-Late Norian, the DP/HD carbonate system is characterised by the drowning of parts of the inner platform domain due to tectonically-driven subsidence (Norian rift, Jadoul, 1985; Jadoul et al., 1992). Extensional faults controlled the development of a major structural high in the Southern Alps (Trento-Dolomites High) which bordered a wide basin (Lombardy Basin), where an horst and graben setting developed. A similar evolution is recorded in the Central Austroalpine (Berra, 1995; Berra \& Jadoul, 1999).

On the platform top, the end of the DP/HD system is recorded by a gap in the sedimentation frequently associated to subaerial exposure. The sedimentological record of emersion differs according to paleogeography. Emersion is poorly expressed on major highs (as they probably remained continuously above the sea-level and only erosional surfaces developed); at the transition between major highs and basins (where subsidence was higher and thus higher frequency sea-level rises periodically drowned the emerged platform) polycyclic paleosols are recorded, whereas on smaller highs isolated within major basins (as in the case of the Lombardy Basin) emersion is recorded by erosion, directly followed by drowning (which locally led to the development of phosphate crusts which record a depositional hiatus; Gaetani et al., 1998) and change in sedimentation.

We will focus in detail on three different cases: the Sella Massif (Dolomites) the Brenta Dolomites and the paleohighs in the Lombardy Basin.

a) Sella Massif: at the Sella Massif (Dolomites) the top of the thin (about 300; Bosellini, et al., 1996) Dolomia Principale/Hauptdolomit is characterised by dolomitic, polycyclic "terra rossa" paleosols (Fig. 4) which are overlain by shallow-water limestones (Dachstein Fm.). The paleosols are discontinuous and only locally preserved, suggesting that elsewhere they did not form or were likely removed during the following sea-level rise (ravinement surface). South of Piz Boè, the top of the DP/HD system is characterised by an up to $10 \mathrm{~m}$ thick lens of polycyclic paleosols. The top of the dolomitised DP/HD is marked by a breccia bed up to $1 \mathrm{~m}$ thick associated with greenish shales and covered by the calcareous inner platform facies of the Dachstein Limestone. Even if discontinuous, these paleosols clearly record on the Sella high the emersion of the top of the Hauptdolomit, supporting a sea-level fall at the end of the DP/HD system.

b) Brenta Dolomites: in the Brenta Dolomites the top of the typical, dolomitised inner platform facies of the Dolomia Principale is covered by about $30 \mathrm{~m}$ of dolostones and breccias with reddish matrix (Malga Flavona Mb., Dal Piaz et al; 2007). Rare intercalations of grey dolomites, often with tepee structures, are preserved. This unit is sharply overlain by marls and limestones referred to the $\mathrm{Zu}$ Limestone (Fig. 5a). The Malga Flavona Mb. consists of several horizons of "terra rossa" 
dolomitic deposits up to a few decimetres thick. They are rich in breccias with angular clasts of light-grey to reddish dolostones (Fig.5a, b, c). Cavities starting from pedogenic surfaces and cutting the succession for a few decimetres are common. These cavities are filled by fragments of grey dolostones in a fine-grained reddish dolomitic matrix (Fig. 5h). Stratabound breccias layers with irregular bases and red matrix can be interpreted as the results of subaerial karst, whereas the cavities can be classified as cryptokarst (Retallak, 2001). Clasts locally show dark borders (Fig.5 f), probably related to pedogenic alteration. The presence of clasts with different grade of pedogenetic alteration in the paleosols (Fig. 5e, g) indicates that the pedogenetic processes affected also older pedogenetic layers (i.e. the red clasts and the matrix derive from the erosion of older layers of paleokarst and "terra rossa" beds). Nodules (granular peds, micropeds) are common within the reddish matrix of the paleosols. In some layers, traces of roots and rootlets are present (Fig. $5 \mathrm{~g}$ ). Lateral variations are important, as is generally observed for soils related to karst topography (Retallak, 2001).

Locally, microstalactitic cements can be recognised, along with small acicular cements ("raggioni") which are not luminescent in cathodoluminescence. SEM-EDS micromorphological and compositional analyses (Fig. 6) have been performed on pedogenic nodules and residual shales. Analyses indicate the abundance of Fe, mainly concentrated in pedogenic nodules (up to $48 \%$ of $\mathrm{FeO}$ ) but also present in the reddish matrix among the dolomite crystals. $\mathrm{Al}$ and $\mathrm{Si}$ are abundant in the fractures between clasts and in the nodules. The Al/Si ratio reflect a TOT structure of the shales. c) Paleohighs within the Lombardy Basin: the higher subsidence rates of the Lombardy Basin with respect to the Brenta Dolomites are responsible for the development of intraplatform troughs separated by $\mathrm{km}$-wide structural highs during the deposition of the upper part of the Dolomia Principale. Two major fault-bordered highs in Val Brembana are here described (Bracca and Camissinone). At Bracca (Fig. 7) the Dolomia Principale is directly covered, along an irregular surface, by shales with rare intercalations of micritic limestones. The upper boundary of the Dolomia Principale is an erosional surface (Forcella et al., 1996). This surface does not record evidence of paleosols, but a reddish, mm-thick Fe-rich crust is present at the contact between the Dolomia Principale and the overlying Riva di Solto Shale. On the Camissinone high, a few km apart, the platform carbonates are covered by a clast-supported breccia layer up to $4 \mathrm{~m}$ thick, with angular, intraformational clasts up to $10 \mathrm{~cm}$ in size. Dark clasts (black pebbles?) are also present. This breccia layer is locally covered by pockets of grey marly dolostones (up to $1.5 \mathrm{~m}$ thick) containing abundant woody fragments (Jadoul \& De Bonis, 1981). The breccias and the dark marly dolostones are capped by black shales (Riva di Solto Shale). Locally, the occurrence of black phosphatic crusts (up to $10 \mathrm{~cm}$ thick at San Pellegrino), replacing ostracod-rich mudstones in 
sedimentary dykes, likely documents a rapid drowning of some of the Dolomia Principale highs, characterised by reduced sedimentation on their tops.

\section{2) Sedimentary evolution in the intraplatform basins.}

The sharp top of the DP/HD depositional system, marked by paleosols or erosional surfaces on the platform top, has a counterpart within the continuous basinal successions. The basinal facies (Zorzino Limestone and Forni Dolomite in the Southern Alps; Quattervals Limestone in the Central Austroalpine, Plattenkalk in the Northern Calcareous Alps) mainly consist of dark calcareous turbidites which interfinger with talus breccias that were deposited at the toe of fault-controlled slopes. The grain size decreases from the border to the depocentre of the basins. The calcareous turbidites from the DP/HD platform are covered by shales (locally containing thin-bedded and laminated micritic limestones) which mark the beginning of the terrigenous siliciclastic input. In Val Taleggio (Lombardy Basin; Fig. 8) the transition between the basinal calcareous facies (Zorzino Limestone) of the DP/HD system and the overlying formations is well-exposed. In detail, between the dark, bedded turbiditic limestones and the overlying Riva di Solto Shale, a few meters thick calcareous unit was encountered (dark "plattenkalk" facies). Decimetric turbidite beds, which are typical in the Zorzino Limestone, are abruptly covered by dark, fine-grained laminated limestones, 4 to $8 \mathrm{~m}$ thick in average. Bioclasts (mainly bivalves) are common, along with reworked grains. Bedding is thinner and thin parallel lamination is the most common sedimentary structure. Slump folds are frequent. Coated or microbored skeletal grains which are rare or absent in the underlying turbiditic bioclastic-intraclastic limestones are common in these beds. The abundance of strongly microbored and coated skeletal grains between the Zorzino Limestone and the Riva di Solto Shale records reduced sedimentation rates, which likely reflects a decreased carbonate production on the platforms. The decrease of the sedimentary input in the basins suggests a crisis of the carbonate factory, indirectly confirmed by the high concentration of vertebrate remains at this stratigraphic level all over the Lombardy Basin (fishes and terrestrial reptiles, Tintori, 1982; Tintori et al. 1985; Renesto, 2006) and can be ascribed to the emersion of the platform top.

The rapid change in the depositional conditions is also indirectly recorded by the increase in the $\mathrm{Sr}$ content, which abruptly shift from an average value of 418 ppm (stdev: 140; 34 samples) in the Zorzino Limestone to 1132 ppm (stdev: 157; 5 samples) in the condensed interval. Sr content could reflect the prevalence of an aragonite-dominated precursor carbonate during the deposition of the condensed interval, but also changes in the environmental conditions (Munnecke et al., 2008). Although Sr concentration is known to be strongly affected by diagenesis (Melim et al., 2002), the stratigraphic distribution and rapid change in the Sr content in the studied section suggest an 
environmental change of the depositional conditions, such as a rapid decrease of the sedimentation rate.

\section{Discussion}

\section{1) Climate constraints in the Norian-Rhaetian succession}

Evidence of arid climate conditions is recorded in the Western Tethys during the deposition of the DP/HD system. Carbonate facies which were deposited along the Tethys margin were bordered by evaporitic facies deposited in confined basins (Burano Anidrite, Apennine) coastal and continental fluvial to playa environments (Keuper, Germany) under semi-arid to arid climate with strong seasonality (Arnstad Fm.; Shukla et al., 2006). Arid climate conditions probably favoured the early, widespread and pervasive dolomitization of the inner platform facies of the DP/HD system (Frisia, 1991; Iannace \& Frisia, 1993). During the Norian the arid belt probably extended up to more than $40^{\circ}$ of latitude north, as reflected by the distribution of climatically sensitive facies, such as claystones with marine dolomitic intercalations reflecting arid conditions up to northern Europe (Beutler, 1995; Reinhardt \& Ricken, 2000; Steinmergelkeuper Formation; Arnstadt Formation sensu Beutler, 1995), evaporitic deposits in the Anglo-Dutch Basin (situated remote to the marine connection with the Tethys) and the deposition of poorly altered Norian hematite-cemented conglomerates, arkoses, arkosic wackestones, and smectitic mudstones in Denmark, which results from the combination of long, dry seasons, the lack of a permanent vegetation cover and rapid episodic deposition (Ahlberg et al., 2002). Climate reconstructions (Ziegler et al., 2003; Sellwood \& Valdes, 2006) indicate that, during most of the Triassic, the arid belt extended to the equator and a humid equatorial belt was probably absent. The climatic conditions in northern Europe were referred (Ahlberg et al., 2002) to the Triassic mega-monsoon climate, which was characterised by very long dry seasons and temporally concentrated annual precipitation (Kutzbach and Gallimore, 1989; Parrish, 1993).

Close to the Norian-Rhaetian boundary, the stratigraphic record on the northern coast of the Tethys indicates a rapid increase of precipitation. Analyses of the paleosols at the top of the Dolomia Principale (Malga Flavona Mb.) revealed the presence of a TOT structure of the shale, suggesting deposition in subtropical settings characterized by alternating dry and wet seasons (Retallak, 2001). The development of polycyclic soils in the Brenta Dolomites supports a transition toward humid climate settings during the pedogenesis. The base of the Rhaetian shaly succession both on the fault-controlled carbonate highs (hiatuses are documented by erosional surfaces, paleosols or 
phosphate crusts) and in the intraplatform basins is invariantly sharp. Paleontological evidence also strongly supports the transition to humid conditions. In the lowermost Riva di Solto Shale a wellpreserved, delicate fossil dragonfly (Italophlebia gervasutii) has been found. Dragonflies are insects which require fresh water for the egg and nymph stages, documenting close-by emerged lands with freshwater. Occurrence of fresh to brackish waters close to the depositional basin of the Riva di Solto Shale is supported by the presence of the alga Pediastrum sp. (Buratti et al., 2000). In the Central Austroalpine units the base of the Kössen Fm. also records evidence of fresh water input with the presence of Chlorococcale algae (Botryococcus sp., Berra \& Cirilli, 1997). High stressed environment are recognized at the base of the Kössen Fm. in the Northern Calcareous Alps (Golebiowski, 1990), which can be explained with a low salinity (about 25-30 \%o) in the "Kössen sea" (Hallam \& El Shaarawy, 1982). The environmental change is furthermore highlighted by the different type of kerogen in the Zorzino Limestone (DP/HD system) with respect to the overlying Riva di Solto Shale. The Zorzino Limestone is characterised by Type II Kerogen (indicating a prevalence of marine organic matter), whereas the Riva di Solto Shale is characterised by Type III Kerogen (the most common maceral in most humic coals, reflecting organic matter of continental origin) (Scotti, 2005).

The abrupt input of fine siliciclastics, the evidence of fresh water influxes and the change in the type of kerogen can be explained with the existence of rivers transporting from the continental area a large amount of fine-grained terrigenous sediments, which were not delivered during the deposition of the DP/HD system. The transition from dry to humid climate in Europe is recorded not only along the coast of the Tethys, but also in Keuper succession of Europe (i.e. Ahlberg et al., 2002; Korte et al., 2005), with the transition from the Steinmergelkeuper Formation (Arnstadt Formation sensu Beutler, 1995) to the transgressive unit of grey claystones and sandstones of the Rhaetian Keuper Formation (Rhätkeuper/Exter Formation sensu Beutler, 1995).

\section{2) Sedimentary record of environmental changes}

The major, rapid sedimentological changes both on the highs and in the basins at the end of the DP/HD depositional system reflect the transition to new environmental conditions, resulting from two different phenomena: a climate change and a sea-level fall. Sea-level fall is responsible for the emersion of the top of the DP/HD system, which is testified in favourable conditions by preservation of paleosols. Evidence of emersion in some domains are partly missing, due to the persistence of carbonate facies above and below this sequence boundary. Furthermore, considering the environmental settings (reef, backreef and inner platform) it is likely that the ravinement surface at the base of the following transgression could have deleted most of the features related to 
emersion, if present. Evidence of emersion and pedogenesis is preserved where subsidence was sufficient for the deposition and partial preservation of sediments (polycyclic paleosols, i.e. Brenta Dolomites) during the sea-level fall and not only for erosion/karstification. Where subsidence was higher (Lombardy Basin) emersion, if occurred, lasted shortly and was followed by the drowning of the highs, creating the accommodation space for the deposition (first in the basins and later on the highs) of the shales and micritic limestones of the overlying depositional system. The emersion of the platform top, beside favouring pedogenetic processes and karstification/erosion on some part of the carbonate platforms, affected the productivity of the carbonate factory. The sea level fall heavily reduced the carbonate production of the rimmed, flat-topped DP/HD carbonate factory, as documented by condensed carbonate facies in the coeval basins. The concentration of terrestrial reptiles (i.e. Eudimorphodon ranzii and Psephoderma s.p.) in the condensed layer at the top of the basinal facies of the DP/HD system (Zorzino Limestone) has no equivalent in the underlying part of the succession (Renesto, 2006). The stratigraphic position of these fossils supports the emersion of the top of the DP/HD system. The persistence of emerged lands also during the deposition of the basal (close to the Norian-Rhaetian boundary in age) shaly units is documented by the recent finding of a flying reptile in the Central Austroalpine units (Kössen Fm.; Stecher, 2008) and of insects (dragonfly) in the Lombardy Basin. The amplitude of this sea-level fall is not wellconstrained. Field observations suggest that a fall in sea level of a few (speculatively 20-30 m) meters could be sufficient to explain the observed evolution.

This emersion is followed by the input of silt (closer to the European coast, Central Austroalpine units; Berra \& Cirilli, 1997) and clay (Southern Alps) which were absent before. Paleogeographic reconstructions (Marcoux et al., 1993; Ziegler, 1990; Dercourt et al., 2000) suggest that clastics were delivered by major rivers running from the European continent to the Tethys margin. The petrography of the thin and rare fine-grained sandstone and siltstone layers observed in the Kössen beds of the Central Austroalpine indicates erosion of a continental basement (Berra \& Cirilli, 1997). The skeletal component of the basal shaly beds is characterised by abundance of bivalves, foraminifera, echinoderms. This change in skeletal grains with respect to the underlying DP/HD system (mainly algae, bivalves, serpulids and microbialites; i.e. Berra \& Jadoul, 1996) could likely reflect a relative cooling, as suggested by a possible foramol affinity of the grain association type. A large temperature drop in the upper Late Triassic is documented by $\delta^{18} \mathrm{O}$ data (Veizer et al., 1999 and Korte et al., 2005). Recent global carbon-climate numerical models (Godders et al. 2008) suggest a cooler climate during the Rhaetian with respect to previous intervals (i.e. Carnian), associated to a decrease in the $\mathrm{pCO}_{2}$. This supports that the Western Tethys changed its climate conditions form the arid setting (DP/HP system) to humid and probably cooler conditions (Fig. 9). 
This change in climate (which occurred close to the Norian-Rhaetian boundary) is not related to a northward shift of the plates (paleomagnetic latitudes do not change significantly) but should be ascribed to a global cooling of the Earth, which also triggered the sea-level fall. Our data suggest that the end of carbonate production predates the major input of fine grained clastics. Actually, when dark shales began to be deposited, the carbonate factory was almost completely shut down. This time-relation is recorded by a) evidence of starvation in the basins as the consequence of the decreased efficiency of the carbonate factory due to subaerial exposure of structural highs, b) the absence of intercalations of shales within the slope and basinal deposits fed by the Norian carbonate systems and c) by the scarcity of limestones in the basal portion of the shales (when present, they frequently consist of lenses and nodules possibly representing seep-carbonates).

The input of clastics in basins previously characterised by carbonate sedimentation was driven by increased precipitation. According to the paleolatitude data, the global climate condition (close to a climatic maximum) and the distribution of the cyclostratigraphic belts (Perlmutter \& Mattews, 1989 ) it is possible to frame the study area (roughly between $25^{\circ}$ for the Tethys margin to $45^{\circ}$ for northern Europe) between the lower part of belt $4 \mathrm{~b}$ and belts 5 to 6 . Climate reconstructions for the Late Triassic (Ziegler et al., 2003; Sellwood \& Valdes, 2006) indicate that belt 4b possibly extended more to the south than suggested by Perlmutter \& Mattews (1989) for a climate maximum. Belts 4b to 6 are the most sensitive in terms of precipitation changes during a cooling, which is expected to increase the humidity in these cyclostratigraphic belts (Fig. 9c).

Delivery of fine-grained siliciclastics into the Western Tethys was due to a progradation of deltaic bodies from the European continent to the Tethys margin. The change from mainly dolomitic to calcareous and shaly units in the Tethys margin close to the Norian-Rhaetian boundary is thus ascribed to a shift of the southern boundary of the humid temperate belt toward the equator, coupled with a sea-level fall. Climate and sea-level changes result from the same process, which should be identified in a global cooling. The observed major climate change close to the Norian-Rhaetian boundary probably resulted from the constructive interaction of different orbital cycles with different frequencies as documented in other cases (Perlmutter \& Mattews, 1989), even if the cooccurrence of non-periodic events which could have enhanced the effects of orbital changes cannot be excluded (such as increased tectonic activity and volcanic events related to the beginning of the break-up of Pangea).

In the evolution of the DP/HD system in the Western Tethys the following steps can be proposed: 1) efficient shallow-water carbonate production (DP/DH system), documented also by deposition of thick calcareous turbidites and slope breccias in the fault-controlled, highly-subsiding intraplatform basins (Norian); 
2) local emersion of the flat-topped platforms and decreased carbonate production/exportation, inducing starvation in the basins due to a sea-level fall (close to the Norian-Rhaetian boundary); 3) abrupt input of fine siliciclastics during the low stand due to increased precipitation, at least or mainly on the continental areas (Europe) north of the Tethys margin. Where siliciclastics were not delivered, deposition of calcareous reef and backreef facies occurred (Rhaetian Dachstein) ; 4) gradual recovery of the carbonate production and decrease in the siliciclastic input during the next sea-level rise.

Stratigraphical evidence indicates arid to semiarid climate conditions during the deposition of the DP/HD carbonate system (step 1). The input of shales (step 3) which postdates a sea-level fall (step 2) requires a river network for the delivery of the clastics from emerged lands to the Tethys. Increased rainfall on the continental areas which bordered the Western Tethys favoured the delivery of fine-grained clastics in the Tethys at this time. Clastic input was triggered by the southward expansion of the temperate belt (humid climate) and was enhanced by a downward shift of the erosional base level during a global cooling event.

\section{Conclusions}

Flat-topped, rimmed carbonate factories close to emerged lands are prone to record sea-level changes, even of limited amplitude, both in terms of changes in the efficiency of the carbonate productivity and in terms of clastic input form continental areas. Furthermore, the carbonate platforms are essentially biogenic and, accordingly, are strongly climate-sensitive and thus are able to record evidence of major climate change both in terms of temperature and humidity. At the top of the DP/HD depositional system an abrupt sedimentation change is recorded across a sequence boundary by the shift from pure carbonate to fine siliciclastic deposits. The depositional change is coupled with the end of the pervasive early-dolomitization process which characterises all the DP/HD depositional systems (Frisia, 1991), reflecting an important paleoenvironmental change (Iannace \& Frisia, 1993). A reduction of the carbonate shedding was followed by delivery of fine siliciclastics along the Tethys margin. Sedimentological evidence suggests that the decreasing carbonate production was not caused by the input of clastics but predated it. The environmental change was more efficient in halting carbonate production than in delivering fine siliciclastics on the Tethys margin. This gap could be related to the time required for the recharge of the underground water table and for the development of an efficient river drainage system on the European continent. The shift from carbonatic to fine siliciclastic sedimentation along the Tethys margin reflects the increased precipitations and the lowering of the erosional base, recording a sea- 
level fall and a climate change. The transition from dry to humid climate along the Western Tethys coast could thus be related to a modification of the Hadley cells produced by a cooling of the Earth. The latitudinal and geographic position of the Western Tethys margin south of the European continent favours the recording of the effects of large-scale climate change on sedimentation and could represent an important proxy for the study of the consequences of long term climate changes on our planet. The described evolution confirms that it could be misleading to think about a "dry" or "humid" Earth, as it is necessary to frame precipitation changes within the climate belts. The dry vs. humid changes at a fixed latitude are the consequences of a shift, controlled by global climate changes, of the boundary between arid and temperate climate belts. It is thus possible, at the same time, to record opposite trends (humid to dry or vice versa) on the Earth as function of the latitude, as it is proposed in the global cyclostratigraphic model (Perlmutter \& Mattews, 1989) and observed during the present-day global warming (Zhang et al., 2007).

\section{Acknowledgments}

This paper benefited from the comments of two anonymous reviewers whose suggestion improved the readability of the first version of the manuscript. Their contribution, the comments of the Guest Editor N. Preto as well as the interesting discussion with Marco Balini (Milano) on the definition of the Norian-Rhaetian boundary are warmly acknowledged.

\section{References}

Ahlberg, A., Arndorff, L., Guy-Ohlson D., 2002. Onshore climate change during the Late Triassic marine inundation of the Central European Basin. Terra Nova, 14, 241-248.

Bechstädt, T., Brandner, R., Mostler, H., Schmidt, K., 1978. Aborted rifting in the Triassic of the Eastern and Southern Alps. - N. Jb. Geol. Paläont. Abh., 156, 157-178.

Berra, F., 1995. Stratigraphic evolution of a Norian intraplatform basin recorded in the Quattervals Nappe (Austroalpine, Northern Italy) and paleogeographic implications. Eclogae geol. Helv., 88/3, 501-528.

Berra, F., 2007. Sedimentation in shallow to deep water carbonate environments across a sequence boundary: effects of a fall in sea level on the evolution of a carbonate system (Ladinian-Carnian, eastern Lombardy, Italy). Sedimentology, 54, 721-735. Berra, F., Cirilli, S., 1996. Palaeoenvironmental interpretation of the Late Triassic Fraele Formation (Ortles Nappe, Austroalpine Domain, Lombardy). Riv. It. Paleont. Strat., 103, 53-70.

Berra, F., Jadoul, F. 1996. Norian serpulid and microbial bioconstructions: implications for the platform evolution in the Lombardy Basin. Facies, 35, 143-162. 
Berra, F., Jadoul, F., 1999. Stratigraphy, paleogeography and tectonic setting of the Norian succession of the Ortles Nappe (Central Austroalpine, Lombardy, Northern Italy). Mem. Sci. Geol. Padova, 51, 78-89

Beutler, G., 1995. Stratigraphie des Keupers. Quantifizierung der altkimmerischen Bewegungen in Nordwestdeutschland Teil I. Bundesanstalt für Geowissenschaften und Rohstoffe, report 113087.

Bornemann, A., Norris, R.D., Friedrich, O., Beckmann, B., Schouten, S., Sinninghe Damsté, J.S., Vogel, J., Hofmann, P., Wagner, T., 2008. Isotopic Evidence for Glaciation during the Cretaceous Supergreenhouse. Science 319, 189-192.

Bosellini, A., Neri, C., Stefani, M., 1996. Geologia delle Dolomiti. Introduzione geologica. Guida alla Escursione Geologica. Società Geologica Italiana, 78 riunione estiva, San Cassiano, 16-18 settembre 1996.

Buratti, N., Cirilli, S., Jadoul, F., Paganoni, A., 2000. Analisi delle facies organiche nell'Argillite di Riva di Solto (Bacino Lombardo, Sudalpino occidentale): considerazioni biostratigrafiche e paleoclimatologiche. Collana di Studi Accad. Naz. Sci. Lett. Arti di Modena, 21, 51-56.

Cirilli, S., Iannace, A., Jadoul, F., Zamparelli, V., 1999. Microbial-serpulid buildups in the Norian- Rhaetian of Western Mediterranean area: ecological response of shelf margin communities to stressed environments. Terra Nova 11, $195-202$.

Coe, A.L., Bosence, D.W.J., Chuch, K.D., Flint, S.S., Howell, J.A., Wilson, R.C.L., 2003. The sedimentary record of sea-level change. Cambridge Univestity Press, Cambridge.

Cozzi, A., 2002. Facies patterns of a tectonically- controlled UpperTriassic platform- slope carbonate depositional system (Carnian Prealps,Northeastern Italy). Facies, 47, 151-178.

Dal Piaz, G.V., Castellarin, A., Carton, A., Daminato, F., Martin, S., Montresor, L., Pellegrini, G.B., Picotti, V., Prosser, G., Selli L., 2007. Note Illustrative della Carta Geologica d'Italia alla scala 1:50.000, Foglio 042 Malè. APAT - Dipartimento Difesa del Suolo-Servizio Geologico d'Italia, Roma.

Decourt, J., Gaetani, M., Vrielynck, B., Barrier, E., Biju-Dubal, B., Brunet, M.F., Cadet, J.P., Crasquin, S., Sandulescu, M., 2000. Peri-Tethys Atlas. Paleogeographical Maps. Commission for the Geologic Map of the World, Paris, France, 24 maps and explanatory notes: I-XX, $269 \mathrm{pp}$

Dore, M.H.I., 2005. Climate change and changes in global precipitation patterns: What do we know? Environment International 31, $1167-1181$

Embry, A.F., 1997. Global sequence boundaries of the Triassic and their identification in the Western Canada Sedimentary Basin. Bull. Canadian Petrol. Geol., 45, 415-433.

Feist-Burkhardt, S., Götz, A.E., Szulc J., Borkhataria, R., Geluk, M., Haas, J., Hornung, J., Jordan, P., Kempf, O., Michalík, J., Nawrocki, J., Reinhardt, L., Ricken, W., Röhling, H-G., Rüffer, T., Török, Á., Zühlke, R., 2008. Triassic. In: McCann, T. (Ed) The Geology of Central Europe, Volume 2 - Mesozoic and Cenozoic, Geological Society of London 749-822.

Forcella, F., Bellentani, G., Bersezio, R., Jadoul, F., 1996. Cinematica e collasso estensionale dei sovrascorrimenti sudalpini della Val Serina (Prealpi Bergamasche). Geol. Insubr., 1, 79-88.

Frisia, S. (1991). Caratteristiche sedimentologiche ed evoluzione diagenetica della Dolomia Principale (Norico) del Lago d'Idro e delle Dolomiti di Brenta. PhD Thesis, Dip. Sc.Terra, Milano.

Fruth, I., Scherreiks, R., 1984. Hauptdolomit - Sedimentary model (Norian, Northern Calcareous Alps). Geol. Rdsch. 73, 305319. 
Gaetani, M., Gnaccolini, M., Jadoul, F., Garzanti, E. 1998. Multiorder sequence stratigraphy in the Triassic system of the Western Southern Alps. In: de Graciansky, P.C., Hardenbol, J., Jacquin, T., Vail, P.R.(Eds.), Mesozoic and Cenozoic Sequence Stratigraphy of European Basins, SEPM Spec. Publ., 60, 701-717.

German Stratigraphic Commission (ed.) (2002). Stratigraphic table of Germany.

Goddéris, Y., Donnadieu, Y., de Vargas, C., Pierrehumbert, R.T., Dromart, G., van de Schootbrugge, B., 2008. Causal or casual link between the rise of nannoplankton calcification and a tectonically-driven massive decrease in Late Triassic atmospheric C02? Earth and Planetary Science Letters 267, 247-255.

Golebiowski, R., 1990. The Alpine Kössen Formation, a key for European topmost Triassic correlation. Albertiana, 8, 25-35.

Haas, J., Budai, T., 1995. Upper Permian-Triassic facies zones in the Transdanubian Range. Riv. It. Paleont. Strat., 101, 249266.

Hallam, A., El Shaarawy, Z., 1982. Salinity reduction of the end-Triassic sea from the Alpine region into northwestern Europe. Lethaia, 15, 169-178.

Iannace, A., Frisia, S., 1993. Changing dolomitization styles from Norian to Rhaetian in the southern Tethys reals. Spec. Publs Int. Ass. Sediment., 21, 75-90.

Jacobs, D.K., Sahagian, D.L., 1993, Climate induced fluctuations in sea level during non-glacial times: Nature, 361, 710-712. Jadoul, F. (1985). Stratigrafi a e paleogeografi a del Norico nelle Prealpi Bergamasche occidentali. Riv. It. Paleont. Strat. 91, 479-512.

Jadoul, F., De Bonis, A., 1981. Paleogeografia e assetto strutturale delle mineralizzazioni a fluorite nella Dolomia Principale delle Prealpi Bergamasche. L'Industria Mineraria, 1, 19-34.

Jadoul, F., Berra, F., Frisia, S. 1992. Stratigraphy and paleogeographic evolution of a carbonate platform in an extensional tectonic regime: the example of the Dolomia Principale in Lombardy (Italy). Riv. It. Paleont. Strat., 98, 29-44.

Jadoul, F., Masetti, D., Cirilli, S., Berra, F., Claps, M., Frisia, S., 1994. Norian-Rhaetian stratigraphy and paleogeographic evolution of the Lombardy Basin (Bergamasc Alps): Excursion B1, 15th IAS Regional Meeting, 5-38.

Jadoul, F., Galli, M.T., Berra, F., Birilli, S., Ronchi, P., Paganoni, A., 2004. The Late Triassic-Early Jurassic of the Lombardy Basin: stratigraphy, palaeogeography and palaeontology. Excursion P. 68, 32nd International Geological Congress, Florence - Italy, August 20-28, 2004, 36 pp.

Jadoul, F.,Galli, M.T., Muttoni, G., Rigo, M., Cirilli, S., 2007. The late Norian-Hettangian stratigraphic and paleogeographic evolution of the Bergamasc Alps. Geoitalia 2007, pre-Congress field trip guide FW02, 33 pp.

Kachroo, R.K., 1989. Uppermost Triassic Conodonts from the Kössen Formation of the Northern Calcareous Alps (Austria).Jb. Geol. B.-A, 132, 665-676.

Korte, C., Kozur, H.W., Veizer, J., 2005. $\delta 13 \mathrm{C}$ and $\delta 180$ values of Triassic brachiopods and carbonate rocks as proxies for coeval seawater and palaeotemperature. Palaeogeogr. Palaeoclimatol. Palaeoecol., 226, 287- 306.

Kozur, H.W., Bachmann, G.H., 2005, Correlation of the Germanic Triassic with the international scale, Albertiana 32, 21-35.

Krystyn, L., Bouquerel, H., Kuerschner, W., Richoz, S., Gallet, Y., 2007. Proposal for a candidate GSSP for the base of the Rhaetian stage. In: Lucas, S.G., Spielmann, J.A.(eds), The Global Triassic. New Mexico Museum of Natural History and Science Bulletin 41, 189-199.

Kutzbach, J.E., Gallimore, R.G., 1989. Pangaean climates: megamonsoons on the megacontinent. J. Geophys. Res., 94 (D3), 3341-3357.

Berra, F., Jadoul, F., \& Anelli, A. (2010). Environmental control on the end of the Dolomia Principale/Hauptdolomit depositional system in the central Alps: coupling sea-level and climate changes. Palaeogeography, Palaeoclimatology, 
Marcoux J, Baud A, Ricou LE, Gaetani M, Krystyn L, Bellion Y, Guiraud R, Besse J, Gallet Y, Jaillard E, Moreau C, Theveniaut H., 1993. Late Norian (215 to 212 Ma). In: Dercourt, J., Ricou, L.E., Vrielynck, B. (eds), Atlas of Tethys palaeoenvironmental maps. Gauthier-Villars, pp 35-53.

Matthews, M.D., Perlmutter, M.A., 1994. Global cyclostratigraphy: an application to the Eocene Green River Basin. In: de Boer, P., Smith, D.G. (eds), Orbital Forcing and Cyclic Sequences. Int. Assoc. Sedimentol. Spec. Publ. 19, 459-481.

Melim, L.A., Westphal, H., Swart, P.K., Eberli, G.P., Munnecke, A., 2002. Questioning carbonate diagenetic paradigms: evidence from the Neogene of the Bahamas Marine Geology 185, 27-53.

Miller, K.G., Sugarman, P.J., Browning, J.V., Kominz, M.A., Hernandez, J.C., Olsson, R.K., Wright, J.D., Feigenson, M.D., Van Sickel, W., 2003. Late Cretaceous chronology of large, rapid sea-level hanges: Glacioeustasy during the greenhouse world. Geology, $31 / 7,585-588$

Morbey, S.J., 1975. The palynostratigraphy of the Rhaetian stage, Upper Triassic in the Kendelbachgraben, Austria. Palaeontogr, 152, 1-75.

Munnecke, A., Westphal, H., Kölbl-Ebert, M., 2008. Diagenesis of plattenkalk: examples from the Solnhofen area (Upper Jurassic, S-Germany), Sedimentology 55, 1931-1946.

Parrish, J.T., 1993. Climate of the Supercontinent Pangea. J. Geol., 101, 215-233.

Perlmutter, M.A., Matthews, M.D., 1989. Global cyclostratigraphy-A model. In: Cross, T.A. (ed), Quantitative Dynamic Stratigraphy. Prentice Hall, 233-260.

Price, G.D., 1999. The evidence and implications of polar ice during the Mesozoic. Earth-Sci. Rev., 48, 183-210.

Reinhardt L., Ricken W. (2000) The stratigraphic and geochemical record of playa cycles: monitoring a Pangean monsoon-like system (Triassic,MiddleKeuper, S. Germany). Palaeogeogr. Palaeoclimatol. Palaeoecol., 195, 99-124.

Renesto, S., 2006. A reappraisal of the diversity and biogeographic significance of the Norian (Late Triassic) reptiles from the Calcare di Zorzino. Bulletin of the New Mexico Museum of Natural History and Science 37, 445-456.

Retallak, G.J., 2001. Soils of the past. An introduction to paleopedology. Blackwell Science ltd., Oxford.

Rigo, M., Galli, M.T., Jadoul, F., 2009. Late Triassic biostratigraphic constraints in the Imagna Valley (western Bergamasc Alps, Italy). Albertiana, 37, 39-42

Schulz, M., Schäfer-Neth, C., 1997. Translating Milankovitch climate forcing into eustatic fluctuations via thermal deep water expansion: a conceptual link. Terra Nova, 9, 228-231.

Schuurman, W.M.L., 1979. Aspects of Late Triassic palynology. 3. Pa lynology of latest Triassic and earliest Jurassic deposits of the Northern Limestone Alps in Austria and Southern Germany, with special reference to a palynological characterisation of the Rhaetian stage in Europe. Review of Paleobotany and Palynology, 27/1, 53-75.

Scotti, P., 2005. Thermal constraints suggested by the study of the organic matter and thermal modelling strategies. A case history from Southern Alps. In: Corrado, S., Di Giulio, A., Zattin, M., Aldega, L. (Eds.), The Record of Thermal History in Sedimentary Successions: Short Course on Methods and Case Histories. Atti Ticinensi Sci. Terra Spec. Ser., 10, 21-35.

Seidel1, D.J., Fu, Q., Randel, W.J., Reichler, T.J., 2008. Widening of the tropical belt in a changing climate. Nature Geoscience 1, $21-24$.

Sellwood, B.W., Valdes P.J., 2006. Mesozoic climates: General circulation models and the rock record. Sedimentary Geology, 190, 269-287. 
Shukla, U.K., Bachmann, G.H., Beutler, G., Barnasch, J., Franz, M., 2006. Extremely distal fluvial sandstone within the playa system of Arnstadt Formation (Norian, Late Triassic), Central Germany. Facies 52: 541-554.

Spenceley A.P., 2001. Grooves and striations on the Stanthorpe Adamellite: evidence for a possible late Middle - Late Triassic age glaciation. Australian Journal of Earth Sciences, 48, 777-784

Stecher, R., (2008) A new Triassic pterosaur from Switzerland (Central Austroalpine, Grisons), Raeticodactylus filisurensis gen. et sp. nov. Swiss J. Geosci. 101,185-201.

Tintori, A., 1982. Hypsisomatic Semionotidae (Pisces, Actinoptergii) from the Upper Triassic of Lombardy. Riv. It. Paleont. Strat. 88, 417-442.

Tintori, A., Muscio, G., Nardon, S., 1985. The triassic fossil fishes localities in Italy. Riv. It. Paleont. Strat. 91, 197-210.

Veizer, J., Ala, D., Azmy, K., Bruckschen, P., Buhl, D., Bruhn, F., Carden, G.A.F.,Diener, A., Ebneth, S., Godderis, Y., Jasper, T., Korte, G., Pawellek, F., Podlaha, O.G., Strauss, H., 1999. Sr-87/Sr-86, delta C-13 and delta 0-18 evolution of Phanerozoic seawater. Chem. Geol. 161, 59-88.

Zankl, H., 1971. Upper Triassic carbonate facies in the Northern Limestone Alps. Sedimentology of part of Central Europe, VIII Int. Sediment. Congress, 147-185.

Zhang, X., Zwiers, F.W., Hegerl G.C., Lambert, F.H., Gillett, N.P., Solomon, S., Stott, P.A., Nozawa, T., 2007. Detection of human influence on twentieth-century precipitation trends. Nature, 448, 461-465.

Ziegler, P.A., 1990. Geological Atlas of Western and Central Europe, 2nd edn. Shell Internationale Petroleum, Maatschappij.

Ziegler, A.M., Eshel, G., McAllister Rees, P., Rothfus, T.A., Rowlet, D.B., Sunderlin, D., 2003. Tracing the tropics across land and sea: Permian to present. Lethaia, 36, 227-254.

Zamparelli, V., Cirilli, S., Iannace, S., Jadoul, F., Berra, F., Boni, M., Claps, M., Climaco, A., Cozzi, A., Podda, F., Ponton, M., Trombetta, G., 1999. Paleotectonic and paleoceanographic control on microbial-serpulids communities in the NorianRhaetian carbonates of Italy: a synthesis. Palaeopelagos spec. Publ., 3, 1-83.

\section{Figure caption}

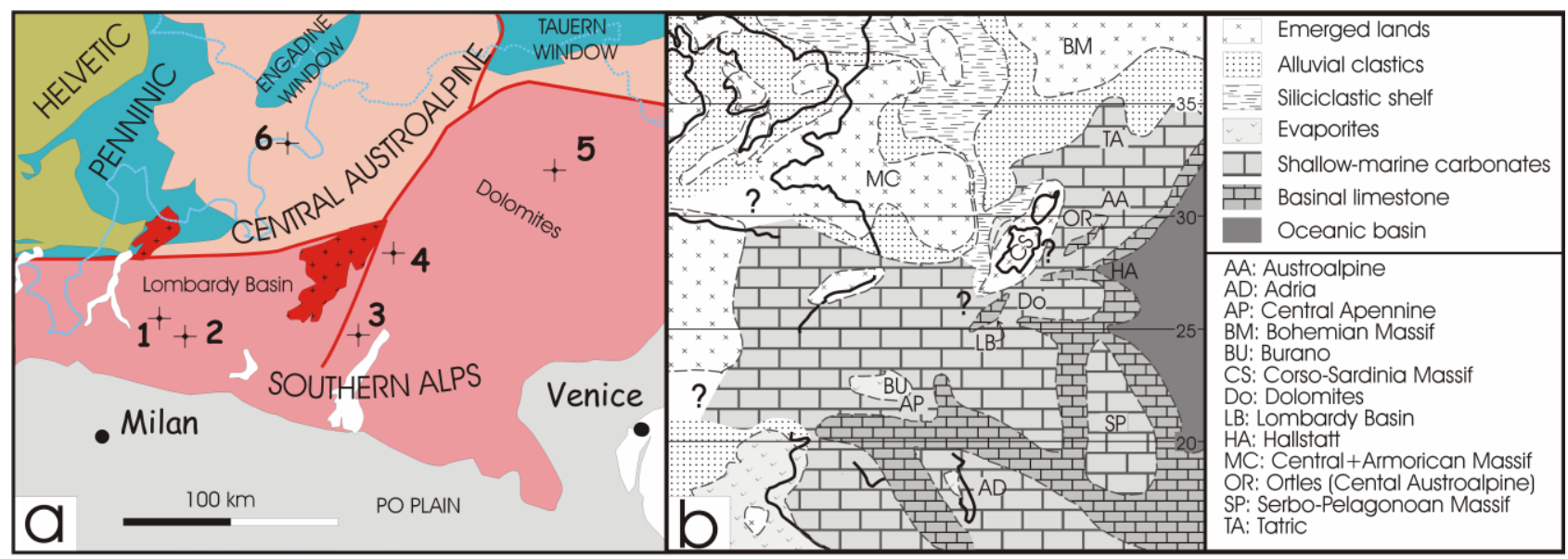

Fig. 1: Geographic (left) and paleogeographic (right) settings of the study area. Paleogeography modified from Marcoux et al., 1993). Numbers refer to sites mentioned in the text. 1: Val Taleggio; 2: Bracca; 3: Tremalzo; 4: Brenta Massif: 5: Sella; 6: Ortles and Quattervals Nappes (Central Austroalpine). 


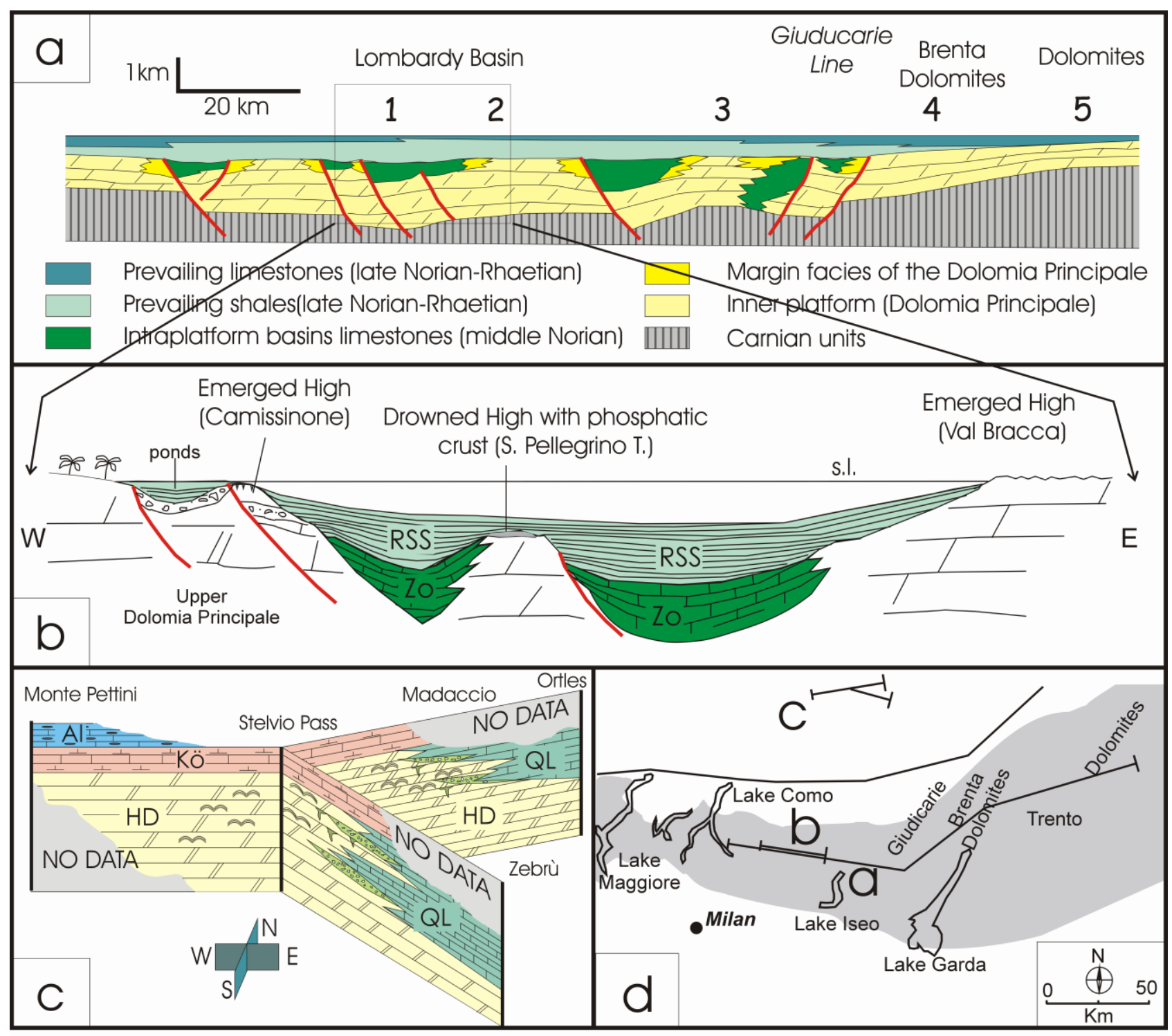

Fig. 2: Stratigraphic setting of the DP/HD systems and overlying units in the Southern Alps and in central Austroalpine. a) simplified stratigraphic reconstruction along a west to east section across the Southern Alps (modified after Jadoul et al., 1992; for the meaning of the number, see fig. 1); b) Detail of the Norian to Rhaetian succession in the central Lombardy Basin (modified after Jadoul et al., 1994) RRS: Riva di Solto Shale; Zo: Zorzino Limestone; c) Stratigraphy of the Norian to Liassic succession in the Ortles Nappe, Central Austroalpine (from Berra \& Jadoul, 1999) HD: Hauptdolomit; QL: Quattervals Limestone (intraplatform basin facies); Kö: Kössen Formation; Al: Allgäu Formation. d) schematic position of the stratigraphic reconstructions (a, b, c refers to the figures). 

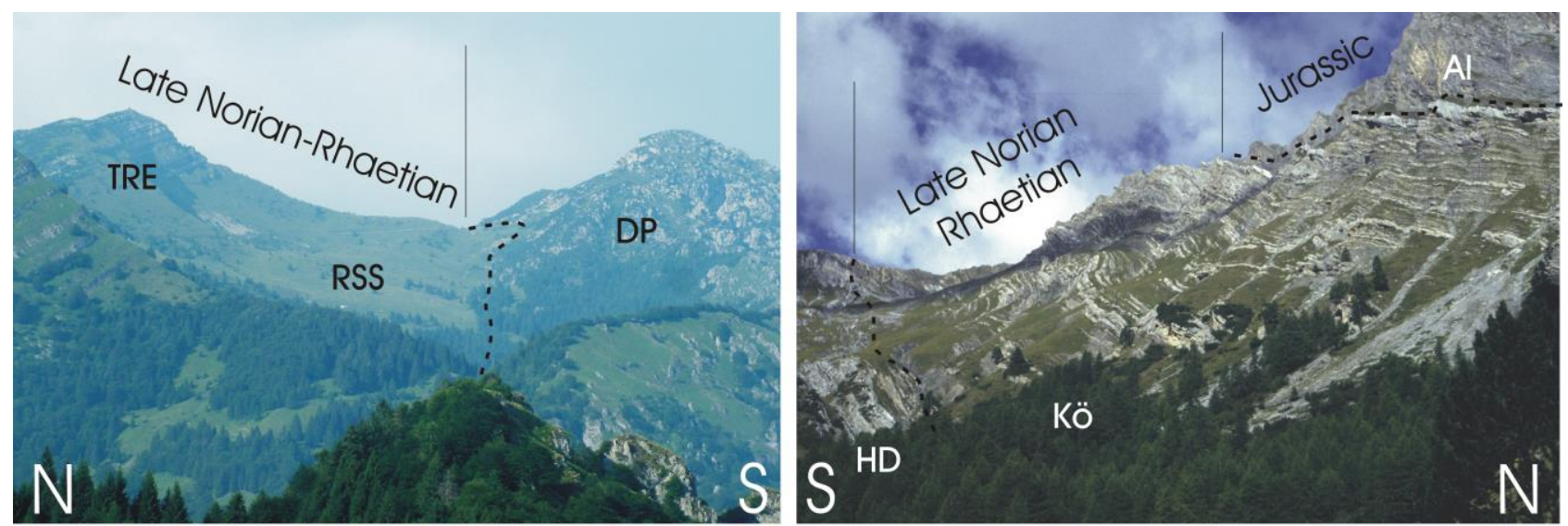

Fig. 3: View of the late Norian-Rhaetian succession at Monte Tremalzo (Southern Alps, eastern Lombardy Basin) and at Monte Pettini, Ortles Nappe, Central Austroalpine. Note the similar thickness and stratigraphic evolution (increase of carbonates and decrease of shales upwards). DP: Dolomia Principale; RRS: Riva di Solto Shale; TRE: Tremalzo Limestone; HD: Hauptdolomit; Kö: Kössen Formation; Al: Allgäu Formation.
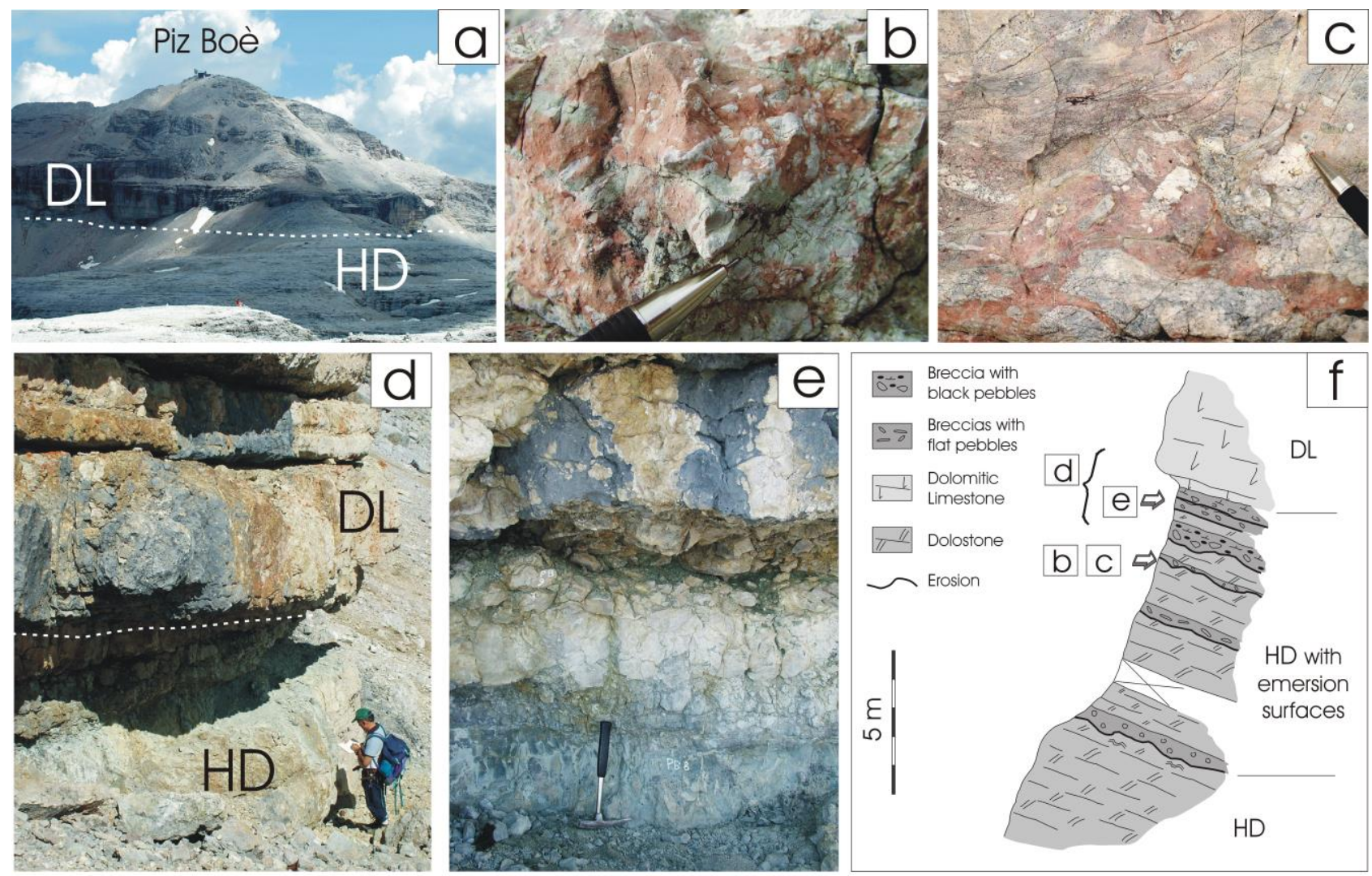

Fig. 4: Top of the DP/HD system, at Piz Boè, Sella platform, Dolomites. HD: Hauptdolomit; DL: Dachstein Limestone. a) view of the contract between HD and DL at Piz Boè. Jurassic units (not indicated in the figure) unconformably cover the DL; b) and c) details of the breccias with red matrix ("terra rossa") showing different degree of pedogenetic evolution, in the uppermost part of the HD; d) base of the calcareous facies of the DL above dolostones and reddish breccias at the top of the HD; e) detail of the uppermost, breccia layer with green shaly matrix, which marks the boundary between the topmost HD and the overlying DL; f) stratigraphic sketch across the boundary between HD and DL. 

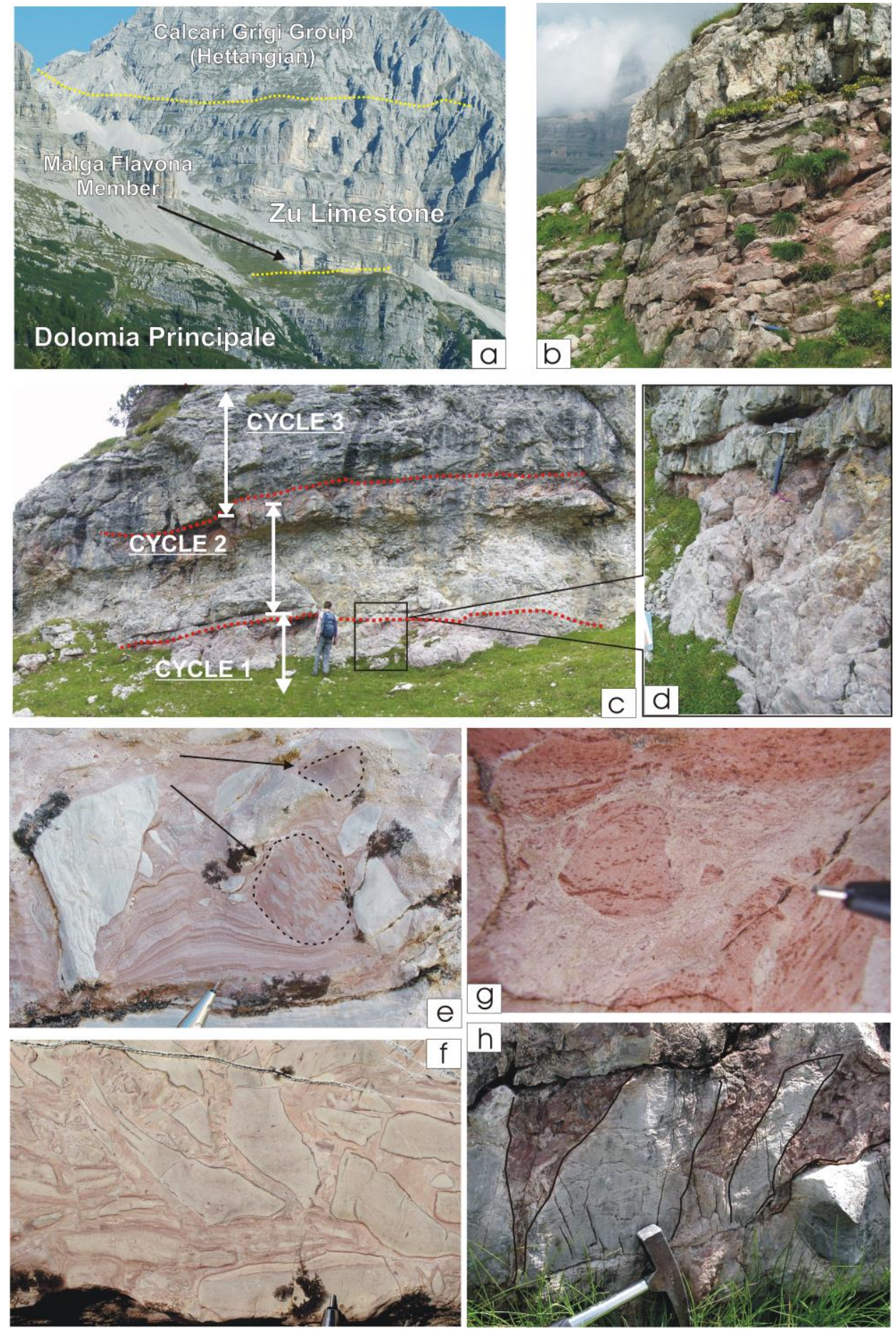

Fig. 5: Malga Flavona Member of the Dolomia Principale in the Brenta Massif. a) view of the Norian-Early Jurassic succession; b) Red paleosols in the Malga Flavona Member; c) view of some pedogenic cycles marked by red paleosols at the top: d) detail of c: note the sharp contact at the base of the new cycle between the reddish breccias and the subtidal-peritidal dolostones which mark the base of the overlying cycle; e) and f) dolomitic breccias with red matrix. Note in e) the presence of clasts which indicate the reworking of evolved paleosols (arrows) with unaltered polygenic dolostones and in f) the presence of altered margins in the angular dolomitic clasts which reflect reduced displacement; g) dolomitic breccias with red, heavily altered clasts (the dark spots are interpreted as micropeds and root traces) and ; h) erosional pockets filled with "terra rossa" deposits (regolith?). 

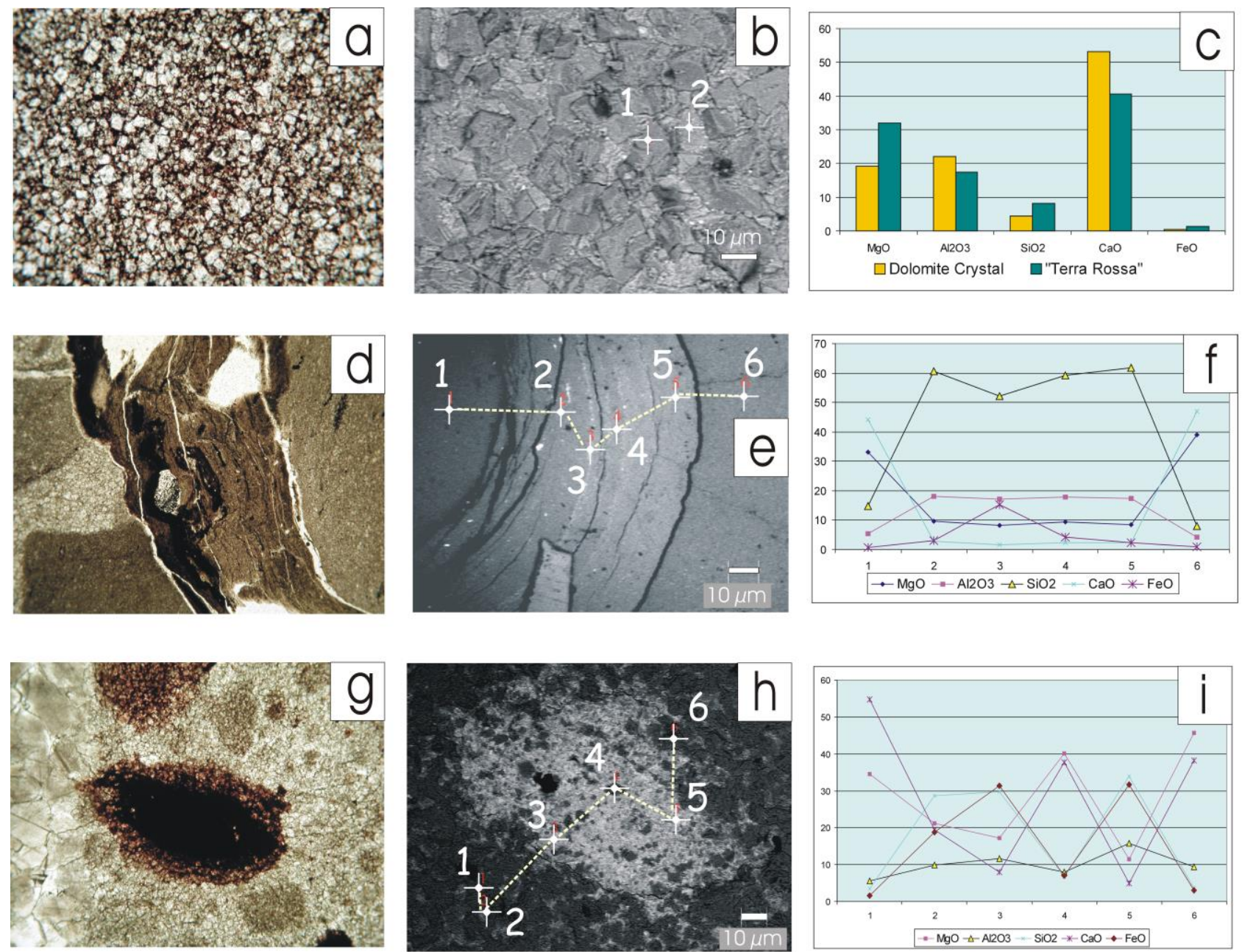

Fig. 6: Details and chemical analyses of the paleosols in the Malga Flavona Member. a) microfacies of a dolomitic pseudosparite: the original texture has been completely destroyed (x40, N//); b) SEM image of the same sample: the dolomite crystals (1) growing in the terra rossa (2) are recognisable; c) EDX analysis of site 1 (dolomite crystal) and of site 2 (terra rossa); d) detail of a small dark clay-rich fracture in a dolomitic mudstone (thin section); e) SEM image showing the concentric lamination within the fracture filling; f) chemical analyses (EDX) along a section across the fracture: sites 1 and 6 show a dolomitic composition, whereas sites 2, 3 and 4 (filling of the fracture) record a high content in $\mathrm{Si}$. The $\mathrm{Si} / \mathrm{Al}$ ratio indicates a T-O-T clay structure (type 2/1 clay); g) Brownish nodule within lighter fine-grained dolosparite (thin section); h) SEM image of the nodule. The lighter core of the nodule indicates a heavier molecular weight; i) EDX analyses of the nodule: the inner part of the nodule (sites 3 and 5) is characterised by a higher Fe content, together with a high content in $\mathrm{Si}$ and $\mathrm{Al}$ (presence of clay minerals). 

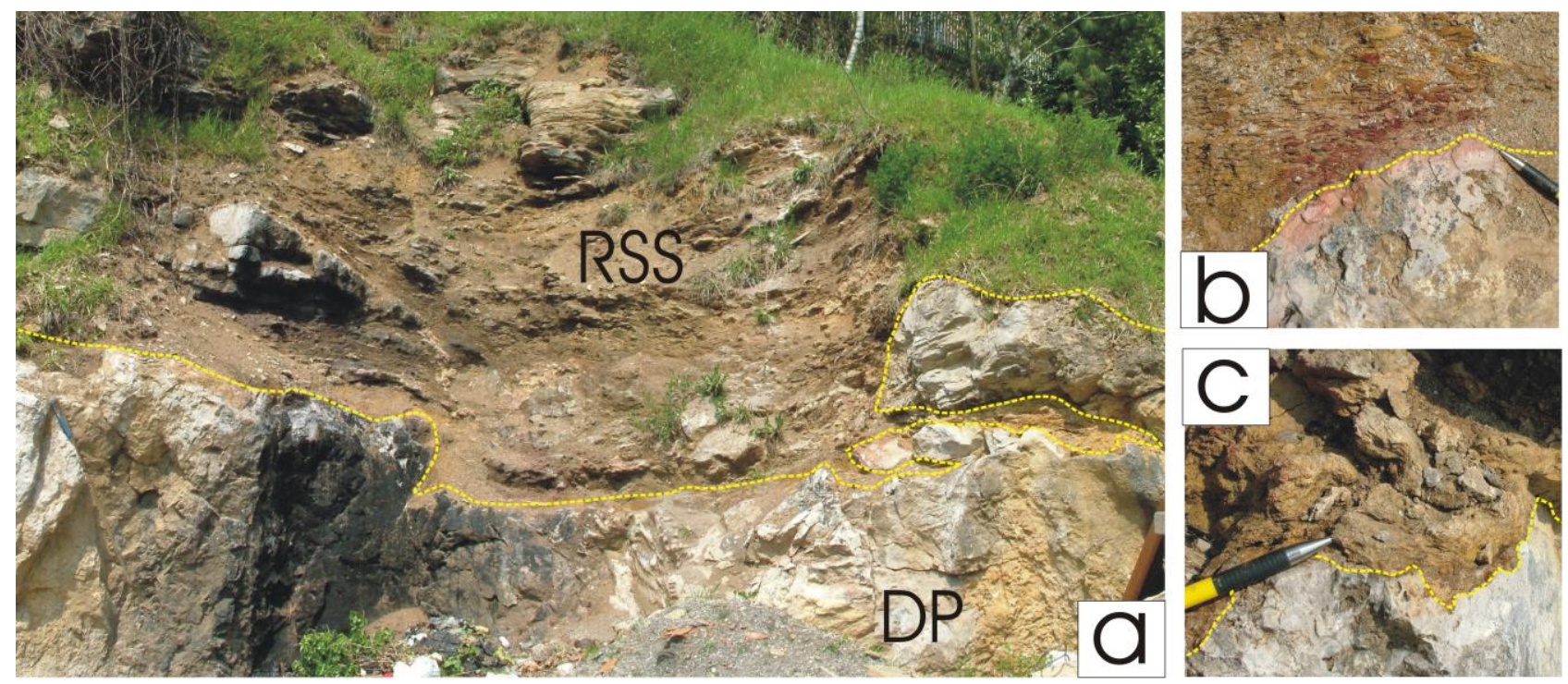

Fig. 7: Sedimentological evidence of the emersion of a high in the Lombardy Basin (Bracca). a) irregular erosional surface at the top of the Dolomia Principale, covered by the dark fine-grained clastics of the Riva di Solto Shale; b, c) details of the contact between Dolomia Principale and Riva di Solto Shale. In b) the dolomite at the contact is reddish. Note in c) the irregular erosional surface (karst?) mantled by the shales. RSS: Riva di Solto Shale; DP: Dolomia Principale. 


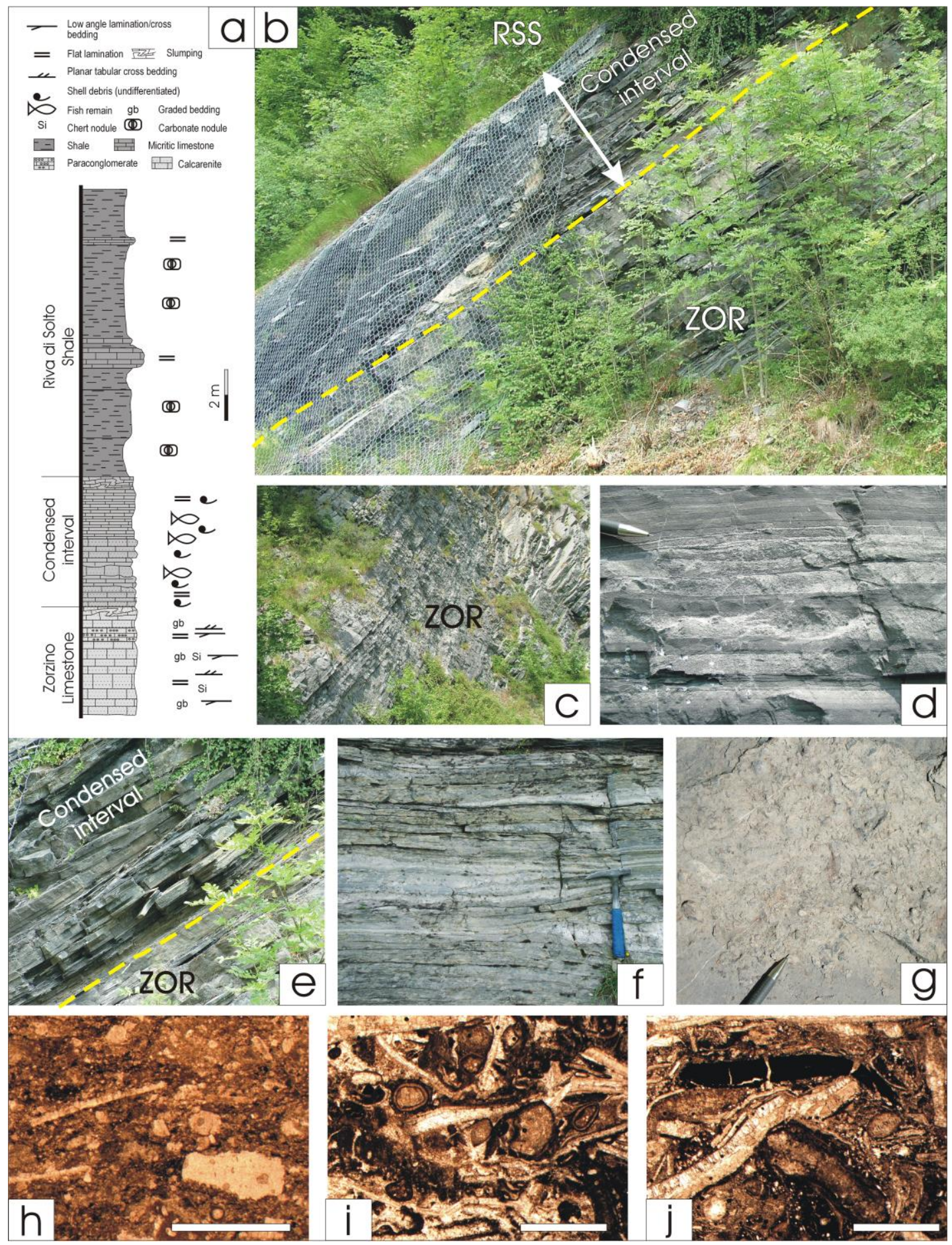

Fig. 8: sedimentological features of the tip of the DP/HD depositional system recorded in the intraplatform troughs of the Lombardy Basin. a) Stratigraphic column of the transition between Zorzino Limestone and Riva di Solto Shale in Val Taleggio; b) view of the sharp contact between the turbiditic facies of the Zorzino Limestone and the condensed interval; c) view of the typical association of the resedimented carbonates of the Zorzino Lst.; d) detail of a turbiditic bed (intrabioclastic packstone); e) detail of b; f) condensed interval at Monte Tremalzo: note the similar facies of the condensed interval in e, Val Taleggio; g) bioclastic bed in the condensed interval; $h$ ) microfacies of a turbiditic bed in the Zorzino Limestone. Note the unaltered skeletal grains; i), j) microfacies from the condensed interval. Note the abundance of coated and microbored grains, indicative of high reworking and low-sedimentation rates (scale bar in $\mathrm{h}, \mathrm{i}$ and $\mathrm{j}$ is $1 \mathrm{~mm}$ ). 


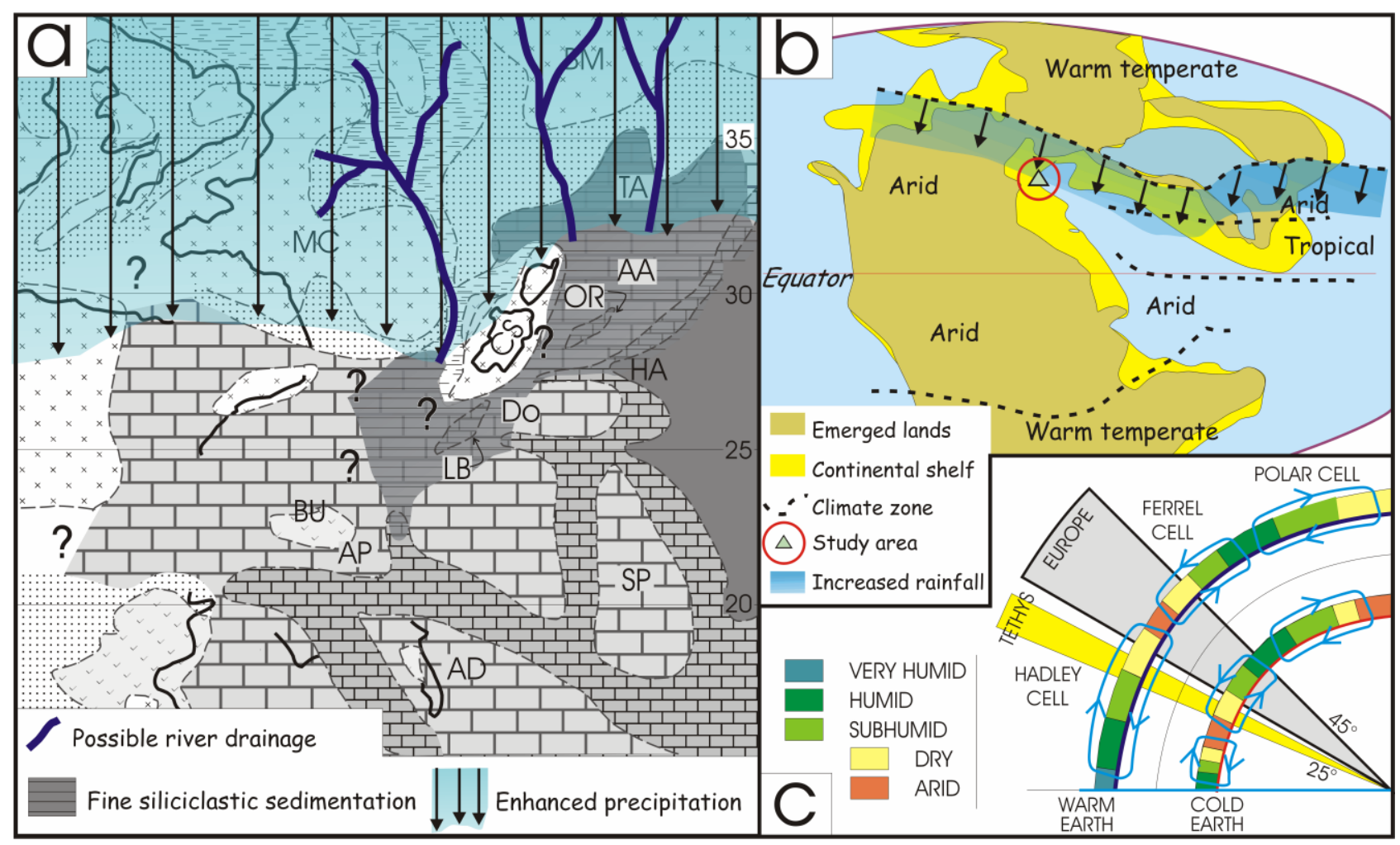

Fig. 9: a) tentative paleogeographic reconstruction of the western Tethys margin during the fine siliciclastic input in the late Norian. The N-S arrows indicate the possible extend of the humid belt. Paleogeographic setting explain the absence of fine siliciclastic on carbonate highs to the south; b) possible global effects of the shift of the boundary between climate belts on Pangea; c) relationship between latitude and climate belts during warm and cold Earth (from Perlmutter \& Matthews, 1989) with the latitudinal position of the Tethys margin and Europe: note how a climate change from warm to cold Earth is responsible for the zonal shift of the Hadley cells and could explain the observed change from dry to humid climate in Europe and part of the Tethys margin. Abbreviations as in Fig. 1. 